\title{
CHANDRAN, NAIR \\ CONSUMPTIONOMICS. ASIA'S ROLE IN RESHAPING CAPITALISM AND SAVING THE PLANET \\ (OXFORD: INFINITE IDEAS, 2011)
}

\author{
Nubia Nieto \\ Consultora independiente \\ nubia.niet@gmail.com \\ Recibido: 18/07/2011 \\ Aceptado: 10/10/2011
}

Chandran, Nair (2011). Consumptionomics. Asia's Role in reshaping capitalism and saving the planet. Oxford: Infinite ideas, 206p.

Consumptionomics is an extraordinary book which offers an innovative insight about a new model of development that can reshape the rules of capitalism. Nair Chandran, who is the director of the Global Institute for Tomorrow (GIFT), an independent social venture think tank based in Asia, argues that this region has the potential to reshape capitalism and create a new economic model for the twenty-first century.

According to Chandran, who has lived and worked in Asia, Europe and Africa, and currently lives in Hong Kong, considers that consumption has been for many years the fuel that drives the engine of global capitalism. The recent financial crisis has seen the West's leading economists and policy makers urging Asia to make a conscious effort to consume more in order to save the global economy. However, for Chandran if Asians achieve consumption levels taken for granted in the West the results would be environmentally catastrophic across the globe.

Chandran, born in Malaysia from Indian parents, points out that Asia must rewrite the rules that have driven growth until now. According to the business consultant, Asians must reject the consumption-driven ways that powered the 
West to global dominance and replace them with new practices, ones that constrain human impact on the environment.

The author of consumptionomics notes that Asia needs to rethink its pattern of growth for a simple reason: there are not many resources for everyone, particularly for Asians who will be between 5 and 6 billions by 2050. Chandran, who is also a specialist in leadership development, corporate social responsibility with ethics, sustainability and globalization, stresses that the World can not follow the Thomas Friedman idea: "the dream of living like Americans".

In agreement with Chandran, today the average American uses 250 Kilowatt hours of power a day. In China, the average is 40 kilowatt hours, and in India it is 20 Kilowatt hours. If Asia's population were to use as much energy per person as Americans, then they would consume fourteen times as much power as the United States does now. Even if Asia were to restrict itself to European energy levels -around 150 kilowatts hours per person per day-it would still use eight to nine times as much energy as America does now.

Another example given by Chandran about the disproportionate industrial development is the car industry. In 1990 China had a few hundred thousands vehicles. In 2009, it surpassed the United States to become the world's biggest auto market, with some thirteen millions of vehicles sold, and it is estimated that China's total vehicles stock will catch up with that of the United States in the late 2020s, when both countries will have around 330 million vehicles. It will then rise to between 470 million and 660 million by mid-century not far off the 820 million or so vehicles in the world's total vehicle fleet today. In 2005, China's vehicle fleet used 109 million tonnes of oil; by 2050, it will need between six and ten times as much. Finding sources for this will be hard.

In this scenario, Chandran, who has been the Chairman of Environmental Resources Management, affirms that the conventional solutions of markets, innovation, technology and finances, can not provide solutions for the world. The idea of opening markets and encourage democracy to catch up industrial development can not be applied for Asia because this region has different cultural, economic, historical and social background than the West.

The Asia's leader in environmental consulting, whose clients included more than 500 companies and multilateral agencies such as the World Bank, the United Nations Environment Programme, and the Asian Development Bank argues that Asia can not follow the same path of industrialization than the West. He considers that Asia has come late to the party. The party has created a lot enjoyment for a few, but there are not enough resources to maintain the party open for everyone. In other words, Asia has jointed the party at the wrong time. 
Currently, the Asian countries account for some $\$ 30$ trillion of world product; by 2050, averaging real growth of just over 5 percent a year, that would be at least $\$ 230$ trillion, between seven and eight times greater than now. Therefore, Chandran urges to Asian governments to constrain consumption trends, because the world does not have enough raw materials to maintain the same speed of growth based on consumption.

Chandran, who is also the co-founder and Chairman of Advantage Ventures, an Asian-based social investment company that supports entrepreneurship and local economic development as key drivers of poverty alleviation in the region, warns about the difficulty to stop the consumption trend in Asia due to the colonial mentality, which makes Asians to emulate Western patterns.

Today, he says, more than 2.2 billion people in Asia have access to mobile phones, far more than have access to potable water or sanitary toilets. That's means that Asians are more worried for catching up the west consumption trend than maintaining their natural resources and health care. The water available to each citizen in Asia is a serious threat and there is not so much awareness about this issue. India's per capital renewable water resources fell 7 percent from 2000 to 2005, and China's by 5 percent.

In this framework, Chandran indicates that Asia needs also rethink its priorities of development and the amount of money allocated to encourage social programs. He quotes the forecast of the World Bank, in terms that developing countries will need to spend a total of between $\$ 40$ to $\$ 100$ billion every year from now until 2050 on adapting to the effects of climate change on their farming sectors.

The idea of modernization in Asia can not be the same than in the West countries. Modernization needs to be redefined in the Asia context. The modernization in this region should be focused on proving better education, health care for the poorest, water sanitation, access to land, and better opportunities for the citizens.

Chandran Nair makes a call to the Asian scholars to overcome the colonial trauma and start to create their own development pattern. Now, he says, it is the time for Asia to stop to look for ideas at the Harvard School and think what does Asia need from the Asian point of view?

The western model has reached its limits. It may have won the Cold war but in its place it upped its war on nature. Capitalism in the West vision need to be reshaped, not replaced. Via markets, it still offers the best machinery for allowing people to choose of goods and pricing according to demand and supply. But it must operate in a framework based around strict resource-management rules, one with constraints on consumption, constructed by pricing in 
external factors and, where necessary incorporating curbs on bans on the use of various resources.

The governments must establish frameworks within which companies operate, ensuring that the environmental impact of their operations is included in costs, that everyone has fair access to the resources they need. Chandran observes that many governments around the world are increasingly aware about the need of controlling industrial development for the well-being of their populations and their economical stability.

The refusal in 2010 of the Indian environment ministry to grant UK based Vedanta Resources permission to mine bauxite in eastern India was a major step in the right direction. South Korea, on the other hand, in 2009 it passed a Low Carbon and Green Growth Act aimed at transforming the heavy industry and manufacturing sectors that dominate its economy. Its goal is to keep its 2020 greenhouse gas emissions total to less than its actual 2005 levels.

For Chandran the main challenge of our century is to control the carbon emissions and consumption trends, and Asia has more chances to create a new sustainable pattern than the West, because for westerners the psychological trauma to renounce or limit their standard of living is high than in Asian. Reducing the level of meat consumption, using cars, traveling by airplane and so on will be very hard to manage for Western governments, even Obama, the president of the United States, Chandran says, can not impose the carbon tax.

He appeals to Asians countries to take their own paths, irrespective of what the West does, and to a large extent irrespective of each other. The key challenge will be ensuring that governments get their priorities rights. Leadership will be important for this, especially from leaders willing to stand and up say that consumption-driven growth is not the answer, that the top priority is making resource management and protection the centre of all policy making, not promoting development blindly through a reliance on market capitalism.

In accordance with the coach of business leaders, Asia can create new forms of society, very different from those traditional rich countries. Asians can engage the world on these issues, particularly China. Chandran also indicates that anything that happen in the Asian region will affect not only the west countries, but the rest of the World, in this sense Asia has an important role in the international development.

The business consultant adds that Asian societies must consider whether they are able to create prosperity without resorting to conventional forms of economic growth. Fiscal and labor policies aimed at strengthening local economies could help both to reduce poverty and prevent migration to cities, the success in both areas could be realized by developing rural credit networks that allowed 
individuals and small business access to funding, not just the micro-credit schemes associated with Banks. Doing so would encourage the growth of rural social enterprises able to offer both rural jobs and local produce.

The text of Consumptionomics sheds light on the new possibilities of development of this century in order to improve standard of living for the majority of the individuals, rather than continuing with the same trend of West capitalism where a tiny elite enjoys all benefits of industrial development. 